\section{IN HOUSE TRAINING (IHT) PEMBELAJARAN DI MASA PENDEMI DENGAN BLENDED LEARNING SMK N 5 DUMAI}

Surya Indrawan', Nur Budi Nugraha², Juni Saputra ${ }^{3}$, Sirlyana ${ }^{4}$

$$
\text { 1,2,3,4 Sekolah Tinggi Teknologi Dumai }
$$

*Nur Budi Nugraha

Email : nurbudinugraha@sttdumai.ac.id

\section{Abstract}

The revolution in information and communication technology occurred during the last few years. During the COVID-19 pandemic that hit Indonesia, all sectors experienced obstacles, including the education sector which was hampered from carrying out teaching and learning activities. Along with the times, the process of teaching and learning activities in the classroom now has many challenges and demands. One-way learning makes the learning atmosphere boring, it is feared that it will affect students' motivation to study the material, so it is modified into blended learning. This model combines offline and online learning, is student centered, namely students must be active in understanding the material, efficient in time, energy, and place because it can be done anywhere. The methods used in this training activity are lectures and discussions, guidance and training. As a result of this blended learning In House Training, all participants actively participated in this activity and participants gained new insights about blended learning strategies that could be implemented in the classroom teaching process during the COVID-1 9 pandemic to become more varied and innovative.

Keywords: blended learning, In House Training, students, learning

\begin{abstract}
Abstrak
Revolusi dalam teknologi informasi dan komunikasi terjadi selama beberapa tahun terakhir. Dalam masa pandemi covid 19 yang melanda Indonesia menjadikan seluruh sektor mengalami kendala termasuk sektor pendidikan yang terhambat untuk melakukan kegiatan belajar mengajar. Seiring perkembangan zaman proses kegiatan belajar mengajar di kelas kini sudah memiliki banyak tantangan dan tuntutan. Pembelajaran satu arah membuat suasana pembelajaran menjadi membosankan, dikhawatirkan akan mempengaruhi motivasi siswa untuk mempelajari materi, untuk itu dimodifikasi menjadi blended learning. Model ini menggabungkan pembelajaran offline dan online, bersifat student centered yakni siswa harus aktif dalam memahami materi, efisien waktu tenaga, dan tempat karena bisa dilakukan dimana saja. Metode yang digunakan dalam kegiatan pelatihan ini yaitu ceramah dan diskusi, bimbingan dan pelatihan. Hasil dari In House Training blended learning ini seluruh peserta aktif mengikuti kegiatan ini dan peserta memperoleh wawasan baru tentang strategi pembelajaran blended learning yang bisa diimplementasikan ke proses kegiatan mengajar dikelas selama masa pandemi covid 19 menajdi lebih variatif dan inovatif.

Kata Kunci: blended learning, In House Training, siswa, pembelajaran
\end{abstract}


In House Training (IHT) Pembelajaran di Masa Pendemi dengan Blended Learning SMKN 5 Dumai

Surya Indrawan, Nur Budi Nugraha, Juni Saputra, Sirlyana

Volume 1, No. 3, Desember 2021 hal. 240-246

DOI Artikel: 10.46306/jub.v1i3.45

\section{PENDAHULUAN}

Revolusi dalam teknologi informasi dan komunikasi terjadi selama beberapa tahun terakhir. Perubahan itu mempengaruhi perilaku keseharian masyarakat dalam berinteraksi dengan orang lain (Amin, 2017). Layanan - layanan baru mulai muncul karena adanya kemajuan e-teknologi. Perusahaan mengambil tren baru mengenai informasi di mana orang tidak perlu untuk bergerak untuk mendapatkan informasi (Nugraha \& Handayani, 202I). Bahkan pemerintah mulai membuat layanan yang memanfaatkan internet untuk memberikan informasi kepada masyarakat (Hidayat et al., 2020). Dalam masa pandemi virus Covid19 yang melanda Indonesia menjadikan seluruh sektor mengalami kendala termasuk sektor pendidikan yang terhambat untuk melakukan kegiatan belajar mengajar, mulai dari tingkat pendidikan dasar hingga tingkat universitas (Sari, 202I).

Seiring perkembangan zaman proses kegiatan belajar mengajar di kelas kini sudah memiliki banyak tantangan dan tuntutan (Juni et al., 202I). Salah satunya adalah semakin banyaknya jalur informasi yang dapat diakses oleh siswa hingga terkadang tidak jarang guru tertinggal jauh dari update-nya informasi yangs udah diterima oleh siswa (Istiningsih \& Hasbullah, 20I5). Oleh karena itu guru pun seolah-olah dipaksa harus mengimbanginya dengan mencari berbagai informasi tambahan menggunakan berbagai media seperti akses internet dan buku refrensi terbaru dan up to date (Aini, 202I). Selain terkait dengan konten materi pembelajaran, saat ini juga telah muncul berbagai macam alternatif strategi belajar mengajar yang dapat diterapkan oleh guru, sehingga guru tidak hanya terpaku pada satu model pembelajaran saja (Aini, 202I).

Pembelajaran satu arah membuat suasana pembelajaran menjadi membosankan, dikhawatirkan akan mempengaruhi motivasi siswa untuk mempelajari materi, untuk itu dimodifikasi menjadi blended learning (Maskar et al., 2020). Model ini menggabungkan pembelajaran offline dan online, bersifat student centered yakni siswa harus aktif dalam memahami materi, efisien waktu tenaga, dan tempat karena bisa dilakukan dimana saja (Sugandi et al., 202I). Kemampuan guru dalam memberikan pengajar juga perlu ditingkatkan sehingga siswa mampu menerima materi dengan baik dan cepat memahaminya (Nugraha et al., 2020).

$\mathrm{Di}$ era revolusi industri 4.0, berkembang platform yang mendukung dalam pembelajaran daring, misalnya Edmodo. Edmodo adalah salah satu media aplikasi yang cukup banyak memiliki fitur untuk mendukung pembelajaran, dan yang penting, akun Edmodo dapat diperoleh tanpa berbayar dan juga didesain untuk penggunaan pembelajaran berbasis sekolah (Rachman et al., 2019). Edmodo dirancang berbasis sekolah dan guna mendukung proses pembelajaran, Edmodo dilengkapi dengan beberapa aktivitas pembelajaran, seperti quiz, assignment, poll, grade book, library, award badges, dan parent code. Untuk bahan ajar, Edmodo mendukung bahan ajar berupa file and links (Nurhadi, 2020). Penggunaan Edmodo juga memberikan kesempatan lebih luas kepada peserta didik dalam memanfaatkan fasilitas yang ada, sehingga dapat diperoleh sumber referensi yang tidak terbatas (Suhairi \& Santi, 202I). 
In House Training (IHT) Pembelajaran di Masa Pendemi dengan Blended Learning SMKN 5 Dumai

Surya Indrawan, Nur Budi Nugraha, Juni Saputra, Sirlyana

Volume 1, No. 3, Desember 2021 hal. 240-246

DOI Artikel: 10.46306/jub.v1i3.45

\section{METODE PENGABDIAN}

Pelatihan In House Training Blended Learning membutuhkan berbagai macam persiapan yang harus dipersiapkan mulai dari menentukan tempat pengabdian sekaligus izinnya, menyusun jadwal kerja, materi yang dibutuhkan serta team pengabdian. Pelatihan ini bertujuan untuk memberikan ketrampilan akhir kepada guru guru SMK N 5 Dumai tentang strategi pembelajaran blended learning dan bisa mengimplementasikan ke dalam pembelajaran di kelasnya.

Metode yang digunakan dalam kegiatan pelatihan ini yaitu ceramah dan diskusi, bimbingan dan pelatihan (Mahmud et al., 202I).

I. Metode ceramah dan diskusi digunakan untuk menyampaikan informasi yang berkaitan dengan blended learning, Edmodo, teori-teori tentang Edmodo, serta manfaat menerapkan Edmodo. Selama kegiatan ceramah dan diskusi peserta akan dibekali modul pelatihan

2. Metode bimbingan dan pelatihan digunakan untuk menindak lanjuti dan mematangkan materi blended learning yang telah disampaikan dalam ceramah dan diskusi. Dengan praktek langsung, guru-guru akan lebih memahami dalam menerapkan blended learning di dalam kegiatan belajar mengajar di kelas.

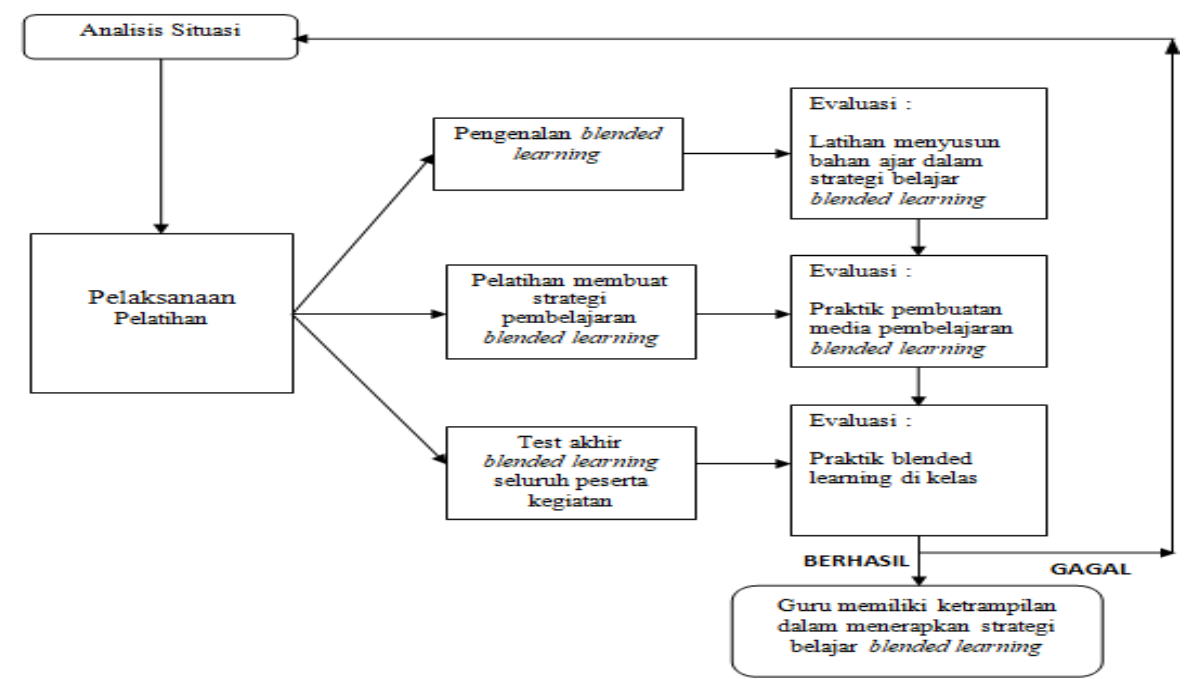

Gambar I. Rancangan Evaluasi Pelatihan

\section{PELAKSANAAN DAN PEMBAHASAN}

Pelatihan In House Training (IHT) Blended Learning ini dilaksanakan pada hari sabtu-minggu tanggal 78 Agustus 2021 di Aula SMK N 5 Dumai dan dihadiri oleh 20 peserta dengan menerapkan protokol kesehatan yaitu menjaga jarak dan memakai masker untuk seluruh peserta pelatihan. Acara pelatihan ini dibuka langsung oleh Bapak H. Poyong, S. Pd, M. Si selaku kepala sekolah SMK N 5 Dumai dan memberikan pengarahan agar seluruh peserta pelatihan mengikuti kegiatan IHT blended learning dengan baik karena materi ini sangat diperlukan untuk pembelajaran di masa pandemi covid 19. 
In House Training (IHT) Pembelajaran di Masa Pendemi dengan Blended Learning SMKN 5 Dumai

Surya Indrawan, Nur Budi Nugraha, Juni Saputra, Sirlyana

Volume 1, No. 3, Desember 2021 hal. 240-246

DOI Artikel: 10.46306/jub.v1i3.45

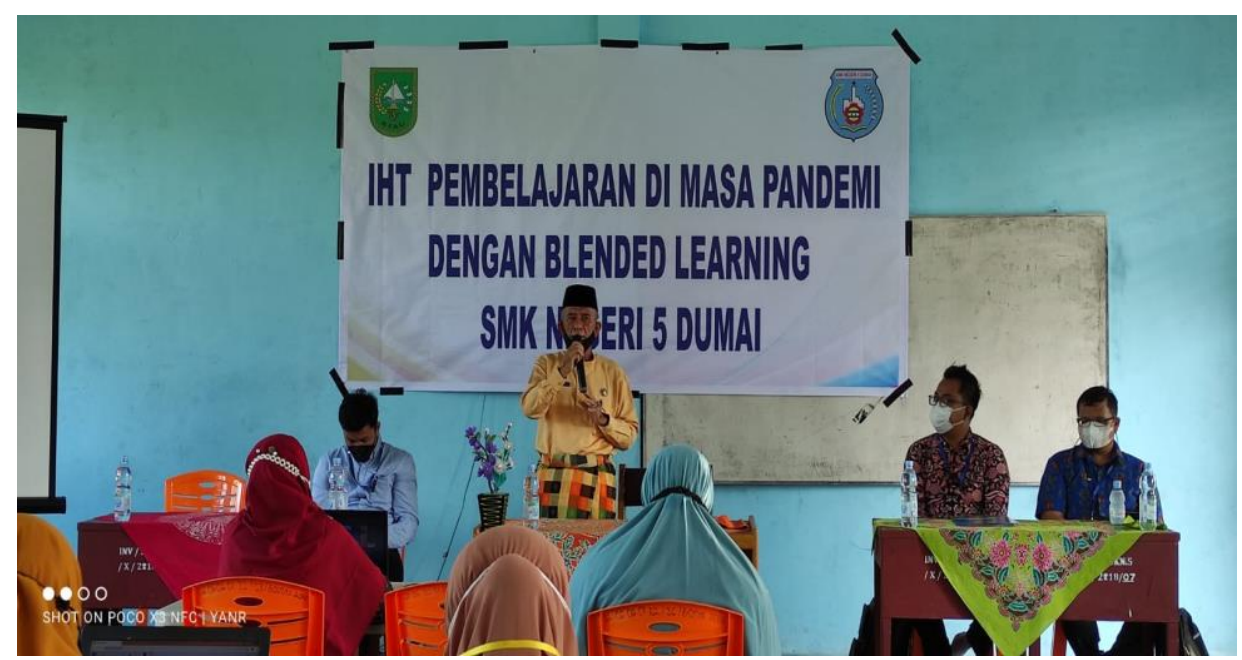

Gambar 2. Pembukaan IHT oleh Bapak Kepala Sekolah

Pelatihan hari pertama difokuskan pada pemaparan materi tentang blended learning. Materi pertama disampaikan oleh Bapak Juni S, MT tentang strategi implementasi blended learning. Sebelum mulai pemaparan, peserta pelatihan diberikan pre test terlebih dahulu untuk mengetahui seberapa besar pengetahuan dari peserta tentang blended learning. Peserta mengerjakan soal yang sudah disediakan oleh team pengabdian dan seluruh peserta sangat bersemangat untuk mengerjakan pre test tersebut. Setelah selesai pre test dikerjakan dan dikumpulkan ke team pengabdian, kemudian bapak Juni memberikan pemaparan tentang strategi pembelajaran blended learning. dalam sesi ini. Dalam sesi ini dosen memberikan informasi mengenai pengertian blended learning, komponen, model belajarnya, kelebihan dan kekurangannya hingga merancang pembelajaran blended learning.

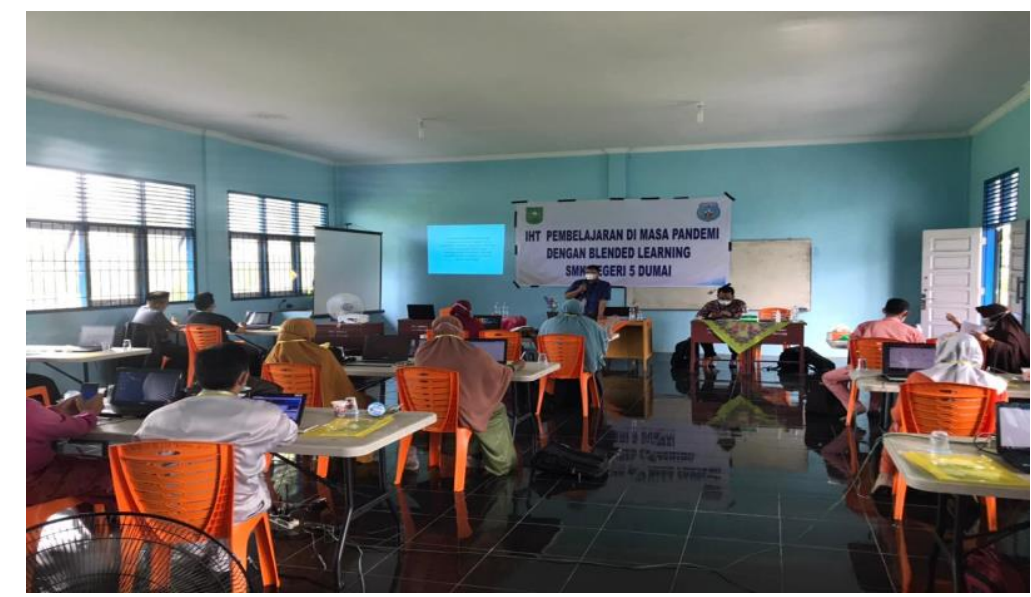

Gambar 3. Pemaparan materi strategi blended learning

Materi kedua disampaikan oleh Bapak Surya Indrawan, MT. pada sesi ini, team pengabdian menyampaikan tentang LMS (Learning Management System). Pemateri memberikan contoh contoh LMS yang bisa digunakan untuk pembelajaran blended learning mulai dari moodle, edmodo, carmen dan lain lain. Selain itu, pemateri juga memberikan materi tentang rancangan silabus pembelajaran yang sudah diselipkan dengan pembelajaran blended learning. Seluruh peserta kegiatan sangat bersemangat ketika pembuatan silabus karena 
In House Training (IHT) Pembelajaran di Masa Pendemi dengan Blended Learning SMKN 5 Dumai

Surya Indrawan, Nur Budi Nugraha, Juni Saputra, Sirlyana

Volume 1, No. 3, Desember 2021 hal. 240-246

DOI Artikel: 10.46306/jub.v1i3.45

hal tersebut sangat berguna untuk seluruh guru. Team pengabdian membimbing seluruh peserta untuk membuat rancangan blended learning yang diimplementasikan ke silabus mereka. Peserta sangat aktif bertanya dan mendengarkan seluruh pemaparan dari pemateri dan diakhir sesi ini seluruh peserta mengumpulkan silabus yang sudah diimplementasi pembelajaran blended learning.

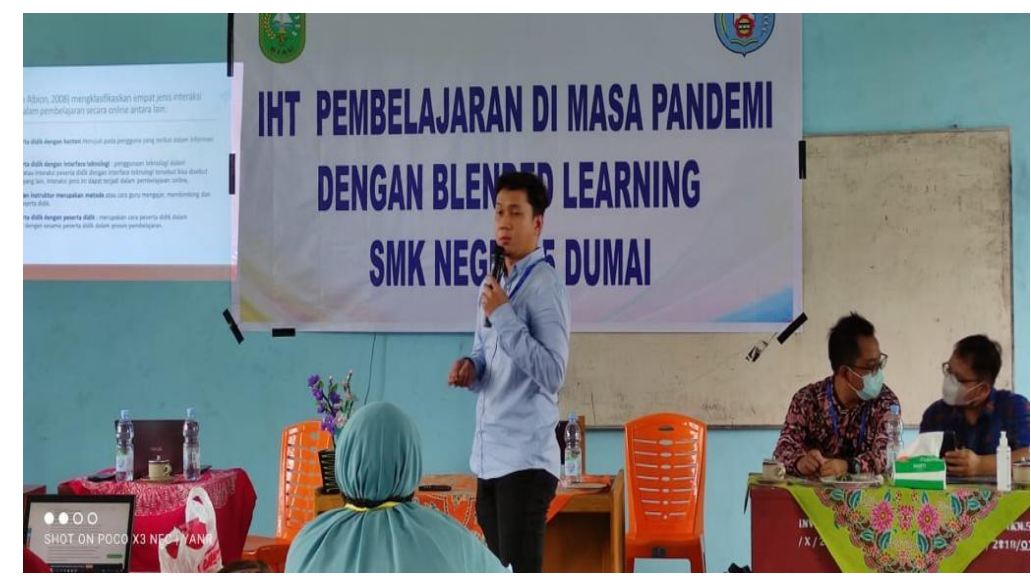

Gambar 4. Pemaparan materi LMS

Pelatihan di hari kedua difokuskan pada praktek langsung pembuatan media pembelajaran blended learning. Pada sesi ini disampaikan oleh Bapak Nur Budi Nugraha, MT dengan memaparkan pembuatan materi dengan salah satu LMS blended learning yaitu menggunakan edmodo. Seluruh peserta dibimbing untuk membuat akun LMS edmodo, mulai dari pembuatan akun edmodo, pembuatan kelas, penguploudan materi, pembuatan soal tugas atau quis dan cara memeriksa jawabannya. Setelah praktek dilakasanakan, kemudian melakukan tes/ujian langsung kepada guru-guru untuk mengetahui seberapa paham mereka tentang fungsi dan penggunaan LMS edmodo.

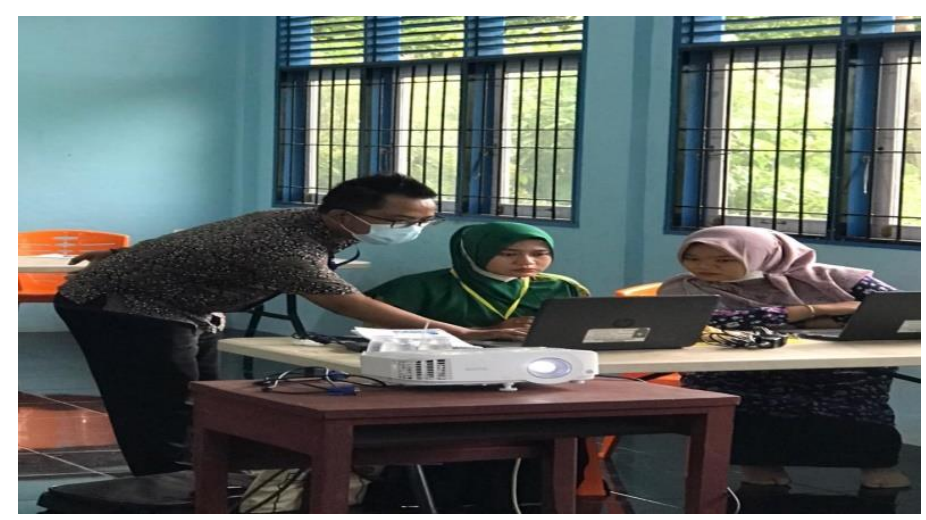

Gambar 5. Praktek Langsung pembuatan LMS edmodo

Pada akhir sesi setelah praktek pembuatan LMS blended learning, team pengabdian memberikan sedikit hiburan berupa game kahoot. Pada sesi ini seluruh peserta sangat antusias dan gembira dengan mengikuti game tersebut. Semua peserta tertawa lepas dikarenakan pertanyaan pertanyaan di game sangat menarik dan unik. Setiap peserta berlomba untuk merebut juara pertama dalam game ini dikarenakan team 
In House Training (IHT) Pembelajaran di Masa Pendemi dengan Blended Learning SMKN 5 Dumai Surya Indrawan, Nur Budi Nugraha, Juni Saputra, Sirlyana

Volume 1, No. 3, Desember 2021 hal. 240-246

DOI Artikel: 10.46306/jub.v1i3.45

pengabdian memberikan doorprise kepada pemenang game tersebut. Seluruh peserta kegiatan sangat puas dengan adanya hiburan ini untuk menghilang kejenuhan setelah belajar selama dua hari.

Secara umum seluruh kegiatan pelatihan selama dua hari ini berjalan sangat lancar. Seluruh peserta yang mengikuti pelatihan merasa senang dan puas dengan kegiatan pengabdian ini, hal ini terlihat dari ungkapan kepuasan serta keantusiasan peserta mendengarkan dan bertanya berbagai hal tentang materi yang telah diberikan oleh para team pengabdian. Di akhir sesi pelatihan ini, team pengabdian mengucapkan terima kasih kepada seluruh peserta kegiatan dan berfoto bersama.

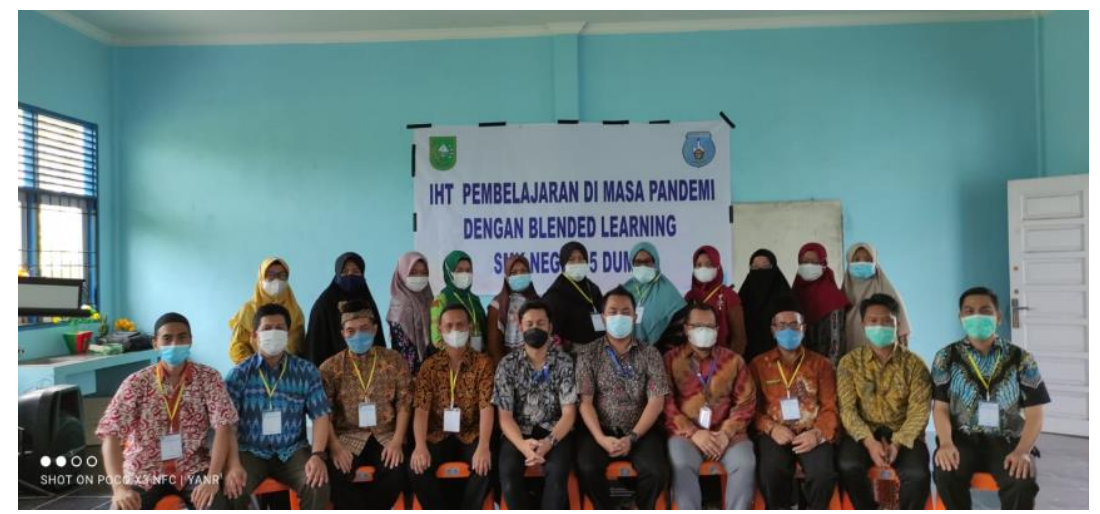

Gambar 6. Peserta IHT dan team pengajar

\section{KESIMPULAN DAN SARAN}

Berdasarkan uraian pelaksanaan kegiatan In House Training blended learning berjalan sangat lancar. Seluruh peserta pelatihan sangat antusias mengikuti kegiatan ini selama dua hari. Mulai dari pemaparan materi strategi pembelajaran blended learning, pengenalan learning manajemen system (LMS) sampai dengan praktek membuat salah satu LMS blended learning. Kegiatan ini diakhiri dengan hiburan berupa game kahoot yang sangat membuat seluruh peserta kegiatan merasa senang dan bersemangat dalam mengikuti kegiatan ini. Seluruh peserta aktif mengikuti kegiatan ini dan peserta memperoleh wawasan baru tentang strategi pembelajaran blended learning yang bisa diimplementasikan ke proses kegiatan mengajar dikelas selama masa pandemi covid 19 menajdi lebih variatif dan inovatif.

\section{UCAPAN TERIMA KASIH}

Penulis mengucapkan terima kasih kepada Ketua Sekolah Tinggi Tinggi Dumai dan Ketua Lembaga Penelitian dan Pengabdian Kepada Masyarakat Sekolah Tinggi Tinggi Dumai yang telah memberikan bantuan dana dalam penyelenggaraan pengabdian masyarakat ini. Selain itu, penulis juga mengucapkan terima kasih kepada panitia dan peserta pelatihan sehingga acara ini dapat terlaksana dengan baik dan lancar. 
In House Training (IHT) Pembelajaran di Masa Pendemi dengan Blended Learning SMKN 5 Dumai

Surya Indrawan, Nur Budi Nugraha, Juni Saputra, Sirlyana

Volume 1, No. 3, Desember 2021 hal. 240-246

DOI Artikel: 10.46306/jub.v1i3.45

\section{DAFTAR PUSTAKA}

Aini, F. N. (202I). Efektivitas Penerapan Model Blended Learning Berbasis Google Classroom Ditinjau dari Motivasi Belajar dan Hasil Belajar Siswa pada Pokok Bahasan Trigonometri Kelas XI IPA-I SMA Hang Tuah 4 Surabaya. BRILIANT: Jurnal Riset Dan Konseptual Volume, 6(2), 303308.

Amin, A. K. (2017). Kajian Konseptual Model Pembelajaran Blended Learning berbasis Web untuk Meningkatkan Hasil Belajar dan Motivasi Belajar. Jurnal Pendidikan Edutama, 4(2), 5 I-64.

Hidayat, M. T., Junaidi, T., \& Yakob, M. (2020). Pengembangan Model Pembelajaran Blended Learning dalam Meningkatkan Pemahaman Siswa Terhadap Tradisi Lisan Aceh. Jurnal Mimbar IImu, 25(3), 402.

Istiningsih, S., \& Hasbullah, H. (20I5). Blended Learning, Trend Strategi Masa Depan. Jurnal Elemen, 4(I), 49-56.

Juni, S., Indrwan, S., \& Nugraha, N. B. (202I). GUNA MENINGKATKAN KOMPETENSI SISWA SMK NEGERI 3 DUMAI. 2(3), 785-790.

Mahmud, S. F., Suarlin, J., \& Nugraha, N. B. (202I). Pelatihan Pemanfaatan Limbah Akar Pohon Hutan Menjadi Hiasan. ABDINE: Jurnal Pengabdian Masyarakat, I(I), 34-40. https://doi.org/l0.52072/abdine.vlil.184

Maskar, S., Dewi, P. S., \& Puspaningtyas, N. D. (2020). Online Learning \& Blended Learning: Perbandingan Hasil Belajar Metode Daring Penuh dan Terpadu. Prisma, 9(2), I54. https://doi.org/I0.35 I94/jp.v9i2.1070

Nugraha, N. B., \& Handayani, T. (202I). PELATIHAN PEMOGRAMAN LARAVEL PADA SISWA SMA IT PLUS BAZMA BRILLIANT. Jubaedah: Jurnal Pengabdian Dan Edukasi Sekolah (Indonesian Journal of Community Services and School Education). DOI: 10.46306/Jub.VIi2 PELATIHAN, I(2), I30-I36.

Nugraha, N. B., Julanos, J., \& Suarlin, J. (2020). Peningkatan Kemampuan Berbahasa Inggris Bagi Siswa SMP. Madani: Indonesian Journal of Civil Society, 2(2), 22-27. https://doi.org// 0.35970/madani.v2i2.206

Nurhadi, N. (2020). Blended Learning dan Aplikasinya di Era New Normal Pandemi Covid-I 9. Agriekstensia, 19(2), 121-128.

Rachman, A., Sukrawan, Y., \& Rohendi, D. (2019). Penerapan Model Blended Learning Dalam Peningkatan Hasil Belajar Menggambar Objek 2 Dimensi. Journal of Mechanical Engineering Education, 6(2), I45-I52. https://doi.org/I0.17509/jmee.v6i2.2I784

Sari, I. K. (202I). Blended Learning sebagai Alternatif Model Pembelajaran Inovatif di Masa PostPandemi di Sekolah Dasar. Jurnal Basicedu, 5(3), 1683-1688.

Sugandi, W., Srifitriani, A., Arga, S. P., \& Kelana, J. B. (202I). Blended Learning Alternatif Pembelajaran Pada Pendidikan Tinggi Era New Normal melalui pembelajaran daring ( Yudiawan, Hana Sakura Putu Arga , Jajang Bayu Covid-19 Pertimbangan pemilihan Pendidikan Geografi antara lain satusatunya program studi di Unive.

Suhairi, S., \& Santi, J. (202I). Model Manajemen Pembelajaran Blended Learning pada Masa Pandemi Covid-19. Syntax Literate; Jurnal IImiah Indonesia, 6(4), 1977. https://doi.org/I0.364I8/syntaxliterate.v6i4.2472 